\title{
The Application of Mind Mapping in Business English Reading Teaching Zheng Weiwei ${ }^{1, a}$ \\ ${ }^{1}$ Jilin Business and Technology College, Changchun, 130507, China \\ azhengweiwei@126.com
}

\author{
Keywords: Mind map; Business English; tool; visualization
}

\begin{abstract}
With the continuous development and improvement of science and technology in China, the use value of mind mapping in Business English reading teaching is becoming more and more obvious. In actual teaching, teachers can scientifically and reasonably on the mind map application, make full use of the advantages and characteristics of the mind map, which makes the discourse teaching more efficiently, improve the English teaching quality and efficiency. British scholar Tony Buzan pointed out that the use of mind mapping, can effectively improve the efficiency of note taking, improve memory and enhance creativity. The application of mind mapping can improve the students' understanding and learning efficiency of teaching content, stimulate students to participate in teaching activities, and help students to achieve the common construction of knowledge. With the development of cognitive linguistics and psycholinguistics, linguists have found that reading is a kind of complex mental activity to obtain information from written language. The reading process is based on the application and processing of the existing linguistic knowledge, and the inference of the deep semantic structure and the deep meaning of the corpus. Therefore, this study through the use of the mind map, show the theme of discourse and details in College EFL reading teaching process, the discourse surface between vocabulary and context and deep relationship, so as to help the students to integrate new and old knowledge structure, realize the internalization of knowledge and meaning construction. Mind mapping is also called mind map, which is a kind of effective visualization cognitive tool invented by Tony Buzan in 1960s. Buzan thinks that mind mapping is the expression of divergent thinking and the natural function of human thinking.
\end{abstract}

\section{Introduction}

Reading teaching has always been an important part of foreign language teaching and learning. The purpose of teaching is to consolidate the knowledge of language through reading and improve the ability of acquiring information in a foreign language. The teaching of business English reading is based on the general English reading teaching, with the purpose of enriching the knowledge structure and developing the ability of acquiring knowledge. In the actual teaching of reading, the students are lack of background knowledge, business vocabulary and reading skills shortage problem such as lack of $1 \mathrm{~J}$, therefore, teachers should pay attention to the import business background knowledge, guide students to predict text content, teaching business English discourse knowledge, enhance the use of business English, students master reading and discourse structure the two pronged strategy, to improve business English reading ability. In the teaching of business English reading, the specific way to effectively improve the level of students' reading comprehension is the content of this paper. The teaching of business English reading can be used for reference to some teaching strategies in English reading teaching, and combined with the characteristics of business English, to expand the teaching strategies of business English text reading and improve the teaching effect. The application of mind mapping in general English reading teaching shows that mind mapping can improve students' reading comprehension ability to a certain extent. Such as: Chai Shaoming (2006) reading teaching of the mind map assisted undergraduate intensive course that the mind map "to help students understand and memorize the text content, promote the student to the deep reading and understanding, improve the students to read the material microstructure, the generalization ability of L2; Huang Xueying (2009) will thinkmap empirical research into senior high school English learning strategy training also shows 
that students map can significantly improve the awareness of discourse by making discourse structure thinking, discourse structure and discourse analysis ability, mind map is the cultivation of students' autonomous learning method.

\section{Mind mapping and its research status}

Mind mapping was founded by Tony, a famous psychologist and educator in the early 1870s in England in the early. It will be left in logical level, text, numbers, and mobilize the right image, imagination, color, space, and other factors, will eventually trace structure thinking with pictures and divergent lines formed on paper. Mind mapping has a high degree of concentration, systematic, visualization and open thinking, practical, can be used for learning, meeting notes, presentations, business discussions and other aspects of decision-making. The students in the classroom more complete by hand, first asked to prepare some crayons and a piece of paper, and then write down the words in the white central theme, and then determine the key words associated with several keywords, use different symbols, colors, pictures and other extended branches, expression of key word content, lower content of keywords according to the branch in order to expand finally, use the arrow to connect the relevant branch, shows the relationship between the connecting part of the. At present, as an effective tool of thinking, the application of mind mapping in teaching has become the focus of scholars at home and abroad. J, both in theory and in practice, has been developed. However, it is still in the experimental stage of how to combine the teaching content and the characteristics of the subject to draw the mind map. It is not enough to guide the students to form the correct business English reading strategies, which is related to the characteristics of mind map and text reading teaching.

\section{The relationship between mind mapping and discourse comprehension}

The mind map can around a center concept quickly diverges into knowledge network, intuitive and strong structure, can clearly show a field of knowledge and the internal relations, is an effective tool to help shape a discourse background knowledge schema. Mind mapping also has a strong system, can promote the user's overall thinking. In the course of discourse reading teaching, text is regarded as a wholeHand, rather than stay on the level of words and phrases to understand the full text, there are similarities. According to schema theory, background knowledge plays a key role in discourse comprehension. In the process of reading comprehension, there are top-down and bottom-up (top - down) (bottom - up) interactive processing model, namely the reader recognition of language knowledge in reading, activate the corresponding background knowledge to predict the contents of the article, according to the text text to form local semantic network, continue to confirm and adjust the prediction, help to understand the contents of the article the intention of the author and judge. The mind map as reading strategies can stimulate the students' active discourse processing, actively looking for points, lines, colors, and the symbols represent the relationship between points, construction of discourse content structure, enhance understanding and memory, therefore, can be said that the mind map as "outside the content structure of text" _8 help on students' reading strategy training. In the classroom teaching, teachers guide the students to make a mind map, urge the students to use the whole discourse reading strategies, to help students develop two-way information correct top-down and bottom-up extraction ability in reading.

\section{Discourse features of business English articles}

Modern business is very focused on timeliness, requirements can be fast and efficient business activities, business English articles with a clear structure, rich in content, novel features. Mastering the characteristics of business English text is helpful to judge and understand the center of the article quickly and accurately. At present, most of the reading materials used in Business English majors are selected from business books, websites and so on. The content involves a large number of business theory and practice knowledge, and most of them are critical articles. Business English 
commentary is usually the first to be commented on the event data in the form of simple description of the background, views and reasons of representative comparison, put forward their own views, opinions and comments at the end of this paper the meaning of events. The structure of the text of the article is logical and coherent, the content of the sentence and sentence, paragraph and paragraph of the semantic coherence between the context of the idea of coherence, and usually follow the first comprehensive analysis of the mode of thinking. The passage part according to the logic of a certain way, such as illustration, definition, classification, causality method, comparative method, process analysis method J. In the text highlight the concise and rigorous features: the title of a high degree of generalization and concise, highly summarized the basic information of the article; paragraph topic sentence is generally located in the first paragraph, paragraph tail. After the title, and important information often appears in the title before and after the article, the logic of the word after the transition is often the focus of the author to emphasize. Read this article, should pay attention to from the beginning of the Title Prediction, prediction of top-down discourse by using background knowledge and chart interpretation information, according to the distribution of all titles, related words and key information of the bottom-up analysis, grasp the overall structure and logic thinking, promote local content and vocabulary in order to improve the efficiency of reading comprehension.

\section{The application of mind mapping in the teaching of business English text reading}

In the teaching of business English reading, because reading content has a certain degree of professionalism, it is particularly important to help students build the background knowledge "scaffolding". The mind map structure, divergent, teachers use it, are the framework points the students are familiar with, easy to understand, to inspire students to think further, to help build the new and old knowledge association, students gradually added business background knowledge, then according to the student's answer and understand the level of the details of the new knowledge show proper flexibility to the actual experience of business theory and the combination of students, improving students' classroom participation enthusiasm. Through the construction of the mind map, we can further develop the students' awareness of the structure of the business English discourse, and strengthen the use of reading strategies to achieve the purpose of improving discourse comprehension and memory. Business English discourse reading teaching, thinkmap application specific steps are as follows: first, teachers in the mind map showing important business background knowledge into key words, to help students understand the construction of the mind map in the background of reading; second, the focus of the article skip, requiring students to use business English the textual knowledge and judgment content points and hierarchy, summed up key words about the structure, tissue showed thinkmap frame; third, to detail questions, guide the students to fill in the mind map framework to enhance its key content, to understand the content of the article details; fourth, with the help of the mind map to retell the article content. Fifth, the integration of supplementary reading content, the establishment of the unit mind map. The "business English Series: Business English reading" products and pricing "in the textbook (product and pricing) unit teaching as an example, the unit contains two long current business English articles, TextA and Text B.

\subsection{Using mind map to construct business background knowledge schema}

The theme of this unit is the impact of pricing (pricing) strategy on product sales profit. Teachers through a variety of resources, such as books, network, collection features, on pricing strategies, function case, using mind map computer software (Mindmanager), will organize information into the mind map, clearly show the relevant information system, pricing strategy. At the same time, the experience on the pricing strategies to inspire students to think and talk about life, and making use of the software according to the students in the field of discussion and speech added thinkmap branch, arouse students' enthusiasm, stimulate the students' knowledge, construct background knowledge schema, a comprehensive understanding of product pricing strategy.According to the teaching material of the Text A background knowledge short reading, according to figure 2 of the paragraph structure of the mind map prompts, require students to short. Then the long Text A to 
provide relevant words, the author's views, etc., students or words to fill in the node after the sub branch content, clear the content of the information should be carefully read the part. When you read the logical relationship between the key points of the background knowledge, and improve the details of the background paragraph, the students are asked to draw up the information points, by understanding the meaning of the passage. Test and help students organize the structure of the background knowledge. According to the information of students reading points outlined and teachers guidance, independently complete the details, and then by the teacher is showing the mind map), which can be predicted from a headline article for the pricing policy branch in brand management, strengthen students' background knowledge schema.

\subsection{According to the characteristics of business English articles, the use of mind mapping}

This part can be divided into: analysis of the problem raised a solution. The content structure of the visual reading, students with TextA in the core vocabulary readahead accepted and stored in the students more about the product pricing strategy that skip the text, understand the structure and the effect. Such as the background of the text, the text into the text reading teaching. Text A of marketing strategy in brand role performance (If brands are marketing strategy for built over years, why are they on brand performance in), myopic (scannermanaged over quarters, myopia) (if the brand can be built for several years, quarter management for data (scanning data), discounting and sales (discount and sales), dashboard approach (a, instrument panel) longerterm perspective and positive results (a more long-term perspective and positive results) as the core issue of reading words. Students can be read in accordance with the key words in the relevant paragraphs, focusing on the first paragraph, paragraph tail and the title of the paragraphs before and after, outlining the main points of information. The students in reading answer questions in the process, a preliminary understanding of the structure, lexical information points after answering the teacher asked the students to combine the background knowledge series known, that the relationship between the contents of each part. Then through the article and summarize the article predicted the meaning of the passage, to fill in the mind map key words or phrases 4, independently, group discussion and exchange of information search skills, promote the application of reading strategies and the understanding of the structure of the article.

\subsection{To integrate the content of reading and establish the unit mind map}

In this paper, two important articles are selected, which are the important problems in the product marketing.Through the Text A reading, students understand the marketing strategy of product pricing strategy, but how to formulate a specific marketing strategy, still need further reading and supplementary reading articles Text $\mathrm{B}$, content system, unique point of view, provide the necessary knowledge. Therefore, teachers in guiding students to read Text $\mathrm{B}$, should contact the unit background knowledge, product marketing as the core, in the framework of marketing strategies of mind map, from the title of "Find the fight iob of your product" (for the right use of products for your hands) prediction of the use of products and marketing. Such as the use of the product (which use conventional use and emergency situation), how to find new uses for those widely accepted, find a new selling point, how to promote the new products with use, to help students to develop thinking, establish a new schema based on existing knowledge on business. Teachers can put these enlightening questions in mind map form, stimulate students' interest in reading, take the initiative to complete the after-school reading, and consciously filled his mind on this unit, a certain knowledge of business structure and business thinking ability. According to the characteristics of business English discourse structure, students can quickly form the overall structure of Text B thinkmap, details of the teacher asked the students of each branch in class, according to the students' reading proficiency and the difficulty, may require individually or cooperatively. Students through reading textbooks in the business English articles, establishes the basic framework of business English knowledge and way of thinking, and then through the extensive extracurricular reading of business English materials, and gradually improve the network business English knowledge of their own, consolidate and improve business English reading level. 


\section{Conclusion}

To explore the mind map as teaching strategies to present business background knowledge to the design, the task of teaching, guide students to actively adopt discourse processing to read the contents of reading strategies in reading, actively build business knowledge network, to enhance the business forecast and understanding ability, and through the completed mind map language repeat, master and store the knowledge of business English, improve business thinking ability. Teachers guide professor of English reading business advantage in thinking, the specific performance in the following five aspects: To the mind map into business with business background knowledge, concise language, large capacity, strong logic, so that students can quickly integrate into the business context and perceived business cultural value. Thinking the map of knowledge organization, presentation and explanation of the key is more prominent, can effectively cultivate students' overall thinking and divergent thinking, improve the students' awareness and ability to use business English texts and background knowledge extraction of information. In the classroom teaching organization, mind map form flexible, convenient for teachers to guide students participating in the construction of visual content schema, stimulate students' imagination, improve the efficiency of classroom teaching and students reading interest. The construction of mind map will motivate students to mobilize all available knowledge for information screening, sorting out the thinking, and actively analyze and establish an orderly business knowledge network. The mind map with the way the brain perception, can enhance students' understanding of the contents of the article to help memory, thereby improving the study of mind map provides a useful attempt in Business English Discourse Reading Teaching application.

\section{References}

[1] M.Pu .Some business English reading course on the optimization [J]. Journal of Shangqiu Vocational Technical College, 2009 (3):117 118

[2] S.M.Chai, Ding Meirong. The application of computer supported mind mapping in College English reading teaching [J]. Chinese educational technology and equipment, 2006 (8): 7-14.

[3] X.Y.Huang,HuZhuju. Mind map into the English learning strategy training experimental study [J]. Foreign language teaching, 2009 (3): 38-42.

[4] M.Dong, C.G.Sun. The study will thinkmap applied to the generation of learning. The network era of science and technology, 2007 (8):91.

[5] ErtugEvrekil et a1. Mind mapping applications in special teaching methods courses for science teacher candidates and teacher candidates' opinions concerning the applications[J]. Procedia Social and Behavioral Sciences. 2009; 2274-2279.

[6] B.Lin,Y.Dong, Q.Y.Guo. An experimental study on the application of mind mapping in Chinese teaching in primary schools in Singapore [J]. Chinese audio visual education, 2007 (10):65 - 68

[7] X.N.Liu. College English teaching from the perspective of the relationship between pictures and texts: a study of mind mapping [D]. Qingdao: Ocean University of China, 2007 